\title{
CHIMERA W SPORACH O TRÓJCĘ ŚWIĘTĄ W LATACH 60. XVI WIEKU (NA PRZYKLADZIE SYLWY IV ANDRZEJA TRZECIESKIEGO)
}

Słowa kluczowe: Andrzej Trzecieski Młodszy, Chimera, antytrynitarze, Stanisław Orzechowski

Keywords: Andrzej Trzecieski Jr., Chimera, antitrinitarian, Stanisław Orzechowski

\section{Czas potworów - niespokojne lata 60. XVI w.}

Sylwa IV Sady prawowierne przeciwko Serwetowym sofistom i zgrai nowych arian (In sophistas Serveticos et novorum arianorum faecem censurae catholicae) jest jedna z trzech (obok III i X) sylw Andrzeja Trzecieskiego Młodszego (przed 1530 - ok. 1584/1585) ${ }^{1}$, przez wydawce pism poety, Jerzego Krókowskiego, określonych jako „polemiczne rozprawy z arianami”2. Zostały one zamieszczone w Sylvarum libri II (1568), zbiorze, który tak tytułem, jak i charakterem nawiązywał do Silvae Stacjusza. Jak twierdzi Roman Krzywy, „staropolska poezja sylwiczna powiązana $\mathrm{z}$ konkretnymi okolicznościami publicznymi bądź prywatnymi [...] skazana była na krótkie trwanie”, a „jej aktualność kończyła się z reguły wraz $z$ chwilą, kiedy opiewane wydarzenie przestawało zaprzątać publiczną uwagę"”. Warto więc, zanim przystąpimy do omówienia sylwy IV i wykorzystanego w niej

${ }^{1}$ Najobszerniejszym, jak dotąd, omówieniem biografii poety pozostaje praca Jerzego Krókowskiego: Andrzej Trzecieski. Poeta-humanista i działacz reformacyjny (Warszawa: PIW, 1954). Cf. też Józef Dużyk, „Trzecieski Andrzej mł.”, in Słownik pracowników książi (Warszawa: PWN, 1972); Tadeusz Witczak, „Trzecieski Andrzej”, in Dawni pisarze polscy od poczatków piśmiennictwa do Młodej Polski. Przewodnik biograficzno-bibliograficzny, vol. 4 (Warszawa: Fundacja Akademia Humanistyczna - IBL, 2003), 270-271.

${ }^{2}$ Jerzy Krókowski, op. cit., 98.

${ }^{3}$ Roman Krzywy, Sztuka wyborów i dar inwencji. Studium o strukturze gatunkowej poematów Jana Kochanowskiego (Warszawa: Wydawnictwo IBL - Stowarzyszenie „Pro Cultura Litteraria”, 2008), 212. 
odwołania do mitycznej Chimery (i Geriona) przyjrzeć się tym „konkretnym okoliczościom”, jakie mogły mieć wpływ na powstanie tekstu. Trzecieski napisał go z pewnością przed 1565 r., może zaraz po sylwie III datowanej na 12 stycznia roku 1564 i adresowanej do księcia meklemburskiego Jana Albrechta, zięcia księcia pruskiego Albrechta Hohenzollerna ${ }^{4}$.

Lata 60. XVI stulecia były okresem niespokojnym w życiu autora wówczas związanego z kalwinizmem i jego możnym protektorem oraz propagatorem Mikołajem Radziwiłłem Czarnym, który zresztą umiera w roku powstania sylwy IV (28 lub 29 maja). Brak spokoju wynikał nie tylko ze wzmożonej aktywności twórczej (łączonej też przez badaczy z pracami nad ewangelickim przekładem Biblii, ogłoszonym w Brześciu nad Bugiem w 1563 r.), lecz również z działalności na rzecz Jednoty, w której doszło do rozłamu i do wyodrębnienia się w $1562 \mathrm{r}$. zboru mniejszego (ariańskiego). Wydarzenie to zostało dobrze rozpoznane i opisane w literaturze przedmiotu ${ }^{5}$, na potrzeby niniejszgo artykułu przypomnijmy zaledwie kilka podstawowych faktów związanych z sytuacją w zborze większym od schyłku lat 50. po roku 1565.

Tezy, z którymi polemizował Trzecieski w sylwie IV, a których głosiciele zasilili szeregi arian polskich, po raz pierwszy otwarcie postawił na synodzie w Seceminie (21-29 stycznia 1556 r.) Piotr z Goniądza. Nawiązał on do poglądów spalonego zaledwie trzy lata wcześniej (27 października 1553 r.) na stosie w Genewie Miguela Serveta, autora De Trinitatis erroribus (1531). W dziele tym Servet krytykował tradycyjne (nicejsko-chalcedońskie) ujęcie Trójcy ${ }^{6}$ kładąc nacisk na preeminencję Boga Ojca objawiającego się ludziom i światu na trzy sposoby

${ }^{4}$ Cf. Jerzy Krókowski, „Komentarz historyczny”, in Andrzej Trzecieski, Carmina. Wiersze łacińskie, ed. Jerzy Krókowski (Wrocław: Zakład Narodowy im. Ossolińskich, Wydawnictwo PAN, 1958), 606. Wszystkie cytaty z utworów Trzecieskiego pochodzą z tego wydania.

${ }^{5}$ Szerzej na ten temat vide Jan Czubek, „Krzysztof Trecy. Przywódca kalwinów małopolskich”, Reformacja w Polsce, vol. 1 (1921): 35-42; Konrad Górski, Grzegorz Pawet z Brzezin. Monografia z dziejów polskiej literatury arjańskiej XVI wieku (Kraków: PAU, 1929); Marek Wajsblum, „O genezę antytrynitaryzmu polskiego", Reformacja w Polsce, vol. 6 (1934): 8-90; Alodia Kawecka-Gryczowa, „Jakób Sylvius a rozłam w zborze małopolskim”, Reformacja w Polsce, vol. 9-10 (1937-1939): 28-63; Lech Szczucki, Marcin Czechowic (1532-1613). Studium z dziejów antytrynitaryzmu polskiego XVI w. (Warszawa: PWN, 1964). Cf. także Akta synodów różnowierczych w Polsce, vol. 2: 1560-1570, ed. Maria Sipayłło (Warszawa: Wydawnictwa UW, 1972).

${ }^{6}$ O kształtowaniu się teologii Trójcy Świętej vide: Elaine M. Wainwright, „Like a finger pointing to the moon: exploring the Trinity in/and the New Testament", in The Cambridge Companion to the Trinity, ed. Peter C. Phan (Cambridge: Cambridge University Press, 2011), 33-48; John Anthony McGuckin, „The Trinity in the Greek Fathers”, in ibidem, 49-69; Michel René Barnes, „Latin trinitarian theology”, in ibidem, 70-85; Bogusław Górka, „Credo Janowego Prologu a credo nicejsko-konstantynopolitańskie”, Przegląd Religioznawczy, vol. 3 (2005): 45-62.

${ }^{7}$ Najpełniejsze przedstawienie biografii Serveta oraz omówienie jego poglądów w polskojęzycznej literaturze przedmiotu znajduje się we wstępie Lecha Szczuckiego do wyboru pism Serveta i dokumentów z nim związanych (dotyczących głównie procesu). Vide Michat Servet (1511-1553). Wybór pism i dokumentów, ed. Lech Szczucki (Warszawa: Książka i Wiedza, 1967), 9-53. 
Wystapienie Gonezjusza obejmowało także krytykę dzieciochrzczeństwa oraz zagadnienie stosunku chrześcijaństwa do urzędu, a literackim odzwierciedleniem jego poglądów stały się pisma: O Trzech, to jest o Bogu, o Synu jego i o Duchu Ś. Przeciwko Trójcy sabeliańskiej, O Synu Bożym, iże byt przed stworzeniem świata, a iż jest przezeń wszystko uczyniono, przeciw fałesznym wykrętom ebijońskim, O ponurzaniu chrystyjańskim przeciwko chrztu nowokrzeczeńców niedawnym, wydane co prawda dopiero w $1570 \mathrm{r}$. w Węgrowie, ale powstałe z pewnością wcześniej, w latach $60{ }^{8}$.

Działalność Piotra z Goniądza zbiegła się z intensywnym udziałem w ruchu protestanckim przybyszów z Italii: Franceska Stankara9 i Giorgia Biandraty (Blandraty) ${ }^{10}$, podobnie jak Gonezjusz zafascynowanych tak postacią Serveta, jak i jego myślą. Od 1558 r. zaczęli oni zyskiwać na znaczeniu w Jednocie, co w połączeniu z ich poglądami (odnośnie do Trójcy, bóstwa Chrystusa, Jego pośrednictwa) wzbudziło niepokój polskich ministrów, m.in. Stanisława Sarnickiego, Jakuba Sylviusa ${ }^{11}$. Nie bez znaczenia był również fakt, że w $1561 \mathrm{r}$. w Lyonie ukazała się książka Confessio evangelica theologiae protheses, piae ac doctae in symbolum Athanasii adnotationes Valenina Gentilego (Gentilisa) ${ }^{12}$, która szybko (podobnie jak i sam autor wraz z innymi osławionymi wyznawcami antytrynitaryzmu: Paolem Alciatem oraz Spinellim) dotarła na ziemie polskie.

Toczące się do kwietnia 1562 r. spory na synodach oraz publiczne dysputy między Stanisławem Sarnickim a Grzegorzem Pawłem z Brzezin ${ }^{13}$ przypieczętowały rozłam, a symboliczny początek nowego kościoła wyznaczył, wedle Karola Górskiego, druk w połowie listopada tego niespokojnego roku Tabula de Trinitate Grzegorza Pawła ${ }^{14}$. Wówczas to ewangelicy reformowani zaczęli podejmować skuteczne działania mające zapobiec zarówno pogłębianiu się podziału, jak i wymierzone przeciwko zwolennikom antytrynitaryzmu. Niekwestionowanym

${ }^{8}$ Cf. Halina Górska, Konrad Górski, Zdzisław Zawadzki, „Wstęp wydawców”, in Piotr z Goniądza, O Trzech, ed. Halina Górska, Konrad Górski, Zdzisław Zawadzki (Warszawa, PIW: 1962), 7; Lech Szczucki, „Piotr z Goniądza”, in Polski Słownik Biograficzny, vol. XXVI/2 (Wrocław: Zakład Narodowy im. Ossolińskich, 1981), 398-401.

${ }^{9}$ Cf. Theodor Wotschke, „Francesco Stancaro. Ein Beitrag zur Reformationsgeschichte des Ostens”, Altpreussische Monatschrift, vol. 47 (1910), 465-498, 570-613; Francesco Ruffini, Francesco Stancaro. Contributo alla storia della Riforma in Italia (Roma: Religio, 1935).

${ }^{10}$ Cf. Antonio Rotondò, „Biandrata Giovanni Giorgio”, in Dizionario Biografico degli Italiani, vol. 10 (1968), www.treccani.it (acc. 9.12.2016). Vide bibliografia, ibidem.

${ }^{11}$ Szerzej na ten temat vide Karol Górski, Grzegorz Pawet..., 48-106.

${ }^{12}$ Vide Stefano Calonaci, „Gentile Valentino”, in Dizionario Biografico degli Italiani, vol. 10 (1968), www.treccani.it (acc. 9.12.2016). Vide bibliografia, ibidem.

${ }^{13}$ Protokoły tych rozmów zawarł w dziele pt. Krótkie wypisanie sprawy, która była, o prawdziwym wyznaniu $i$ wierze, prawdziwego Boga, i syna Jego Pana Jezusa Krystusa Zbawiciela i Pana naszego, także i Ducha św. Pocieszyciela i Doktora naszego... Grzegorz Paweł z Brzezin. Fragmenty in Akta..., 328-352. Omówienie dzieła: Karol Górski, Grzegorz Paweł..., 142-144.

${ }^{14}$ Vide Karol Górski, Grzegorz Pawet..., 103-106, 138-139. Dzieło niestety nie zachowało się. 
przywódcą Jednoty stał się przywoływany już Stanisław Sarnicki ${ }^{15}$, znakomity organizator życia zborowego oraz utalentowany autor tekstów polemicznych. Jego działalność uznać można za emblematyczną dla walki z szerzącą się herezją, była ona bowiem prowadzona zarówno $\mathrm{z}$ wykorzystaniem środków administracyjnych, władzy politycznej, osobistych kontaktów z teologami szwajcarskimi (Janem Kalwinem, Henrykiem Bullingerem) i możnowładcami polskimi (Bonerami, Stanisławem Myszkowskim z Mirowa, Janem Firlejem), jak i piór oraz talentów całego zastępu pisarzy, a także pras współpracujących z nimi drukarzy z Maciejem Wirzbiętą na czele ${ }^{16}$. Na utworach literackich powstałych w tym burzliwym okresie (1562-1566) i nierzadko stanowiących pokłosie konkretnych wydarzeń: sejmów, soborów, publicznych dyskusji, warto się chwilę zatrzymać, by odtworzyć gorącą atmosferę tamtych lat, sprzyjającą, jak zobaczymy, rodzeniu się trójkształtnych monstrów.

Spośród dzieł o bardzo wyraźnym, polemicznym charakterze wskazać trzeba przede wszystkim prace samego Sarnickiego, a mianowicie opublikowane w $1564 \mathrm{r}$. O uznaniu Pana Boga wszechmogacego troje kazanie oraz Collatio in qua aperte demonstratur blasphemia Gregorii Brzezinensis... Niewątpliwie uznać je musimy za odpowiedzi na ogłoszone drukiem utwory Grzegorza, „częściowo”, jak zauważył Konrad Górski, „zwalczające sam dogmat o Trójcy, a częściowo jego obrońców" ${ }^{17}$. Chodzi tu m.in. o: Turris Babel, De Antichristi Deo essentia personato se ipsum expugnante brevis demonstratio, Krótkie wypisanie sprawy, która byta o prawdziwym wyznaniu [...] w Krakowie $i$ w Pińczowie 1563 roku, Antidotum contra articulos fidei novae a Sarnitio Varsaviae exhibitos i polskie thumaczenie tej rozprawy pt. Antidotum. O wyznaniu wiary księdza Sarnickiego i o jego oderwaniu ${ }^{18}$. Sarnicki razem z Grzegorzem uczestniczyli też w dyspucie podczas sejmu piotrkowskiego w 1565 r. (22-30 marca). Jej literackim świadectwem stała się opublikowana przez Sarnickiego broszura Colloquium Piotrkowskie, to jest rozmowa, która mieli wyznawce prawdziwej wiary staradawnej o Panu Bodze $w$ Trojcy jedynym z strona przeciwna $w$ Piotrkowie w Sejm Roku przesz.<tego $>1565$ $(1566)^{19}$. Ciężar dogmatyczny tych sporów dotyczył natury Trójcy, przedwiecznego

${ }^{15}$ Szerzej o działalności Sarnickiego vide Halina Kowalska, Janusz Sikorski, „Sarnicki Stanisław h. Ślepowron", in Polski Stownik Biograficzny, vol. 35 (Warszawa: IH PAN, 1994), 217-223; Wojciech Sławiński, „Stanisław Sarnicki jako działacz reformacyjny (część I)”, Czasy nowożytne, vol.18-19 (2005): 9-113; idem, „Stanisław Sarnicki jako działacz reformacyjny (część II)”, Czasy nowożytne, vol. 24 (2011): 11-35.

${ }^{16}$ Szerzej na ten temat vide Konrad Górski, Grzegorz Pawet..; Marek Wajsblum, op. cit.; Lech Szczucki, Marcin Czechowic... Cf. także Akta...

${ }^{17}$ Konrad Górski, Grzegorz Pawet..., 122.

${ }^{18}$ Cf. ibidem, 122-125.

${ }^{19}$ Szerzej o dyspucie vide Konrad Górski, Grzegorz Pawet z Brzezin..., 133-137; Akta...,175-192; Irene Dingel, Kęstutis Daugirdas, „Historische Einleitung”, in Antitrinitarische Streitigkeiten. Die trinitarische Phase (1560-1568) (Göttingen: Vanderhoeck \& Ruprecht, 2013), 3-17. 
bóstwa Syna Bożego, preegzystencji Syna w Bogu Ojcu, ale także dzieciochrzczeństwa. Wierni Jednocie ewangelicy reformowani wysuwali przeciwko arianom także zarzuty wielobóstwa lub/i wiary w trzy odrębne boskości.

$\mathrm{Z}$ perspektywy naszych rozważań nie można pominąć milczeniem faktu, że kwestie te i debaty nad nimi skłoniły również katolików do zajęcia stanowiska wobec antytrynitarzy i ich przywódców. W gronie polemistów reprezentujących stronę katolicką wymienić należy przede wszystkim Andrzeja Frycza Modrzewskiego oraz Stanisława Orzechowskiego ${ }^{20}$. Pierwszy jeszcze w 1560 r. rozpoczął pracę nad liczącą trzy księgi rozprawą $O$ pośredniku pisaną w obronie Stankara i pod wpływem jego protektorów: Stanisława Drohojowskiego oraz Hieronima Ossolińskiego. Efektem podjętego przez wójta wolborskiego trudu były trzy inne utwory: O grzechu pierworodnym, O wolnej woli człowieka, O Opatrzności i odwiecznej predestynacji przez Boga ${ }^{21}$. Nie pozostały one bez wpływu na zaostrzenie się relacji ze Stanisławem Orzechowskim, co doprowadziło do słynnej teologicznej dysputy w Wolborzu w pałacu biskupa Jakuba Uchańskiego wiosną roku 1561. Ta słowna potyczka zaowocowała takimi tekstami jak: Prosta opowieść (1561) oraz Orzechowski (1562) Frycza i Fricius (1562) Orzechowskiego ${ }^{22}$, który - w przeciwieństwie do Modrzewskiego - ostro i otwarcie występował przeciwko Stankarowi. W 1560 r. wdał się w dyskusję z Włochem, przebywającym wówczas w Dubiecku pod opieką Stanisława Stadnickiego. Rezulatem jej była polemiczna rozprawa $O$ pośredniku (1561), lecz także pełen inwektyw atak na cały ruch różnowierczy zawarty w Wyznaniu wiary, które czynił w Piotrkowie na synodzie 1552, a potem na synodzie warszawskim potwierdzone (1562) i w Listach... (1561), w których, jak czytamy na karcie tytułowej, „naprzeciwko nowym Ewanjelikom dowodzi” się, że kościół katolicki jest „prawdziwy”, „od Krystusa i od Apostołów postanowiony dostatecznie a mądrze" ${ }^{23}$. W wydanym rok później liście

${ }^{20}$ Przywołać tutaj trzeba także luteran polskich, który zajęli stanowisko w sprawie Trójcy Świętej. Najbardziej wyrazistym przykładem jest tutaj De sacrosanctissima Trinitate Erazma Glicznera. Autor kierował swoje dzieło przeciwko zwolennikom Ariusza, Sabeliusza i Gentilisa. Cf. Erasmi Gliczneri Znenensis, De sacrosanctissima Trinitate, orthodoxae ac verisimae observationes, quibus cumulatissime ostenditur, Trinitatem... esse unum illum ac verum Deum (Francoforti ad Oderam: Officina Io. Eichorni, 1565). Korzystałam z egzemplarza Biblioteki Książąt Czartoryskich w Krakowie (sygn. Cim. 883 II).

${ }^{21} \mathrm{Na}$ temat tych dzieł Modrzewskiego, etapów ich powstawania i znaczenia vide Łukasz Kurdybacha, „Wstęp”, in Andrzej Frycz Modrzewski, Pisma 1560-1562, ed. Konrad Górski, trans. Edwin Jędrkiewicz, Irmina Lichońska, Wanda Germain (Warszawa: PIW, 1957), 5-35.

${ }^{22}$ Cf. ibidem, 36-42.

${ }^{23}$ Cf. Listy Stanistawa Orzechowskiego, w których który jest prawdziwy Kościót od Krystusa $i$ od Apostołów postanowiony dostatecznie a mądrze naprzeciwko nowym Ewanjelikom dowodzi (Kraków: Łazarz Andrysowicz, 1561). O relacji Orzechowskiego i Stancara vide ibidem, 21-22; Stanistawa Orzechowskiego i Franciszka Stankara pisma o państwie i religii - „Chimera” $i$ „Reguly reformacji”, ed. Krzysztof Koehler (Kraków: Akademia Ignatianum et Wydawnictwo WAM, 2012), $10-22$. 
do ewangelika reformowanego i promotora kalwinizmu w Wielkim Księstwie Litewskim, Mikołaja Radziwiłła Czarnego, Orzechowski wspomina ogłoszoną w tym samym roku Chimerę..., w której „Boskim [...] natchnieniem pokazuje się pewne Królestwu Polskiemu zginienie, jeśli się rychło wszyscy nie obaczymy, a jeśli od tych sekt sakramentarskich Sarmacyjej, królowi naszemu poddanej, wczas nie wybawimy" ${ }^{24}$. Nieco dalej, polecając lekturę tego dzieła i chcąc do niej zachęcić, tak podsumowuje cel i główny temat utworu:

Nie gniewajże się na Chimerę naszę poćciwy Polaku, ale Panu Bogu za to dziękuj, że tobie objawił przez mię, chude naczynie swe, truciznę od Franciszka Stankara i od buntu jego tobie zgotowaną, którą byś ty pospołu z prawem, z królem, z wolnością i z duszą swą zginą ${ }^{25}$.

\section{Bestia Stanisława Orzechowskiego}

Chimaera sive de Stancari Fvnesta Regno Poloniae Secta (Chimera, czyli o zgubie, jaka Królestwu Polskiemu niesie sekta Stankara) ogłoszona została po raz pierwszy u Łazarza Andrysowicza w Krakowie po 15 kwietnia roku 1562. W roku kolejnym dzieło wytłoczył w Kolonii Maternus Cholinus, a Orzechowski w liście do niego pisał, że decyzję o wznowieniu utworu w zagranicznej typografii podjął m.in. z powodu „haniebnych błędów” popełnionych przez krakowskiego drukarza, które trzeba było usunąć, gdyż są „nazbyt dla czytelnika o wielkim nosie uciążliwe"26. Orzechowski, dziękując Cholinusowi za jego pracę, przypominał o trudnym położeniu, w jakim znalazł się Kościół i o zadaniach, jakie w związku z tym mają do spełnienia tak ludzie pióra, jak i właściciele pras. Od ich postawy zależy bowiem, czy herezja będzie szerzyć się dalej:

Wydałem Chimerę naszą we wspaniałych kopiach, a równocześnie zaznaczyłem w niej, jak wielka pobożność, świętobliwość i religijność jest twoja strzeżona w Kościele Chrystusowym, który zewsząd jest teraz w sposób niezwykle jawny rozdzierany przez heretyków; przeciw tym, zbrodniarzom i bezbożnikom, Bóg, strażnik Kościoła swojego, posłał nie tylko pisarzy [o] bardzo ostrym [w argumentacji języku], lecz także was drukarzy najwierniejszych i najlepszych, bez których, jak lekarze bez aptekarzy, niemal niczego nie są w stanie [zdziałać] pisarze, choćby ci byli uczeni i mocni w mówieniu. Ponieważ między nimi ty służysz nie herezji, lecz pobożności, tym bardziej należy cię chwalić, im bardziej ganić trzeba tych, którzy swój trud nad książkami do atakowania Kościoła Chrystusowego z własnej woli powierzają bezbożnikom i godnym potępienia heretykom, których zaiste dlatego oczekuje ta sama co zbrodniarzy kara, która i owych heretyków w piekle [spotka]. Albowiem bez nich wszyscy heretycy, których nasz czas przyniósł, zaledwie mogliby być podobieństwem najmniejszego poruszenia. Nigdy Luter świętokradcą, nigdy Zwingli niszczycielem Sakramentu, nigdy Balthazar nowochrzczeńcem, nigdy Müntzer

${ }^{24}$ Stanisław Orzechowski, „List do Oświeconego Pana Pana Mikołaja Radziwiłła”, trans. Dominika Budzanowska, in Stanistawa Orzechowskiego i Franciszka Stankara..., 420-421.

${ }^{25}$ Ibidem, 425.

26 „Stanisław Orzechowski typografowi [kolońskiemu] Maternusowi Cholinusowi [przesyła pozdrowienie]", trans. Dominika Budzanowska, in ibidem, 428. 
buntującym chłopów, nigdy Kalwin podżegaczem heretyków przeciw Galom nie stałby się, gdyby pierwej nie służyli im swoją bezbożną tłocznią drukarze, od których ponieważ ty się oddzielasz i działalność swoją drukarską poświęcasz pobożności, miłuję cię, mój Maternusie, i raduję się, że taka rozwaga została ci dana, którą przewidujesz, by nic tak w umyśle, jak i w twojej tłoczni nie było przeciwnego wierze katolickiej ${ }^{27}$.

Słowa, za pomocą których Orzechowski przedstawił chwalebną działalność Cholinusa, wskazywały na słuszność konsekwentnego współdziałania wymierzonego przeciwko odszczepieńcom i zostały powtórzone w dedykacji Chimery... Autor skierował rozprawę do uczestników Soboru Trydenckiego i papieża Piusa IV oraz króla Zygmunta Augusta ${ }^{28}$, ponieważ chciał ich przekonać o swoim szczerym powrocie na łono Kościoła Katolickiego ze „stada brudnych saksońskich świń, uciśnionych i pogrążonych wreszcie przez legion demonów"29. Dowodem konwersji była zaciekła „walka za zgubną Chimerą"30, czyli herezją Stankara, a odnosząca się doń Chimera... stanowiła bezpośrednią odpowiedź na listy mantuańczyka oraz ogłoszone przez niego po łacinie (1550) i po polsku (1553) Canones Reformationis Ecclesiarum Polonicarum - Reguły reformacji Kościołów polskich $^{31}$. Razem z nimi zostały wydrukowane prace m.in. przeciwko przyzywaniu świętych oraz o nauce o Trójcy.

Chimaera... składa się z trzech części, a ich układ oraz treść wyglądają następująco: prezentacja osoby Franciszka Stankara i jego poglądów opartych na błędnych przesłankach, wskazanie źródeł tez stawianych przez Włocha (1), omówienie obowiązków króla (2), nawoływania do zachowania „wiary przodków” (3) ${ }^{32}$. W dwóch pierwszych częśsiach znajdziemy zaś odniesienia do mitycznego monstrum, którego imię zawarte zostało w tytule, a jego sens wyjaśnił Wojciech Wędrogowski w wierszu dołączonym do edycji krakowskiej i kolońskiej:

Co tytuł znaczy księgi tej - Chimera?

Hordzie ów pisarz świetny i wyborny

Imię to nadał Chimer, które w Polsce

Monstrom podobne Bogu dziś złorzeczą.

Eh, może każdy dziś do woli czynić

Rzeczy niegodne wedle widzimisię,

A mędrca rolą jest je opłakiwać ${ }^{33}$.

${ }^{27}$ Ibidem, 428-429.

${ }^{28}$ Cf. Stanisław Orzechowski, „Chimera, czyli o zgubie jaką Królestwu polskiemu niesie sekta Stankara”, in ibidem, 256-260, 269-270. Oprócz tego dzieło zostało opatrzone listem Jakuba Górskiego do Andrzeja Przecławskiego (cf. ibidem, 261-263). Zauważyć warto, że sam Górski w 1563 r. ogłosił Mercurius sive de Trinitate contra Gregorium Bresinensem.

${ }^{29}$ Stanisław Orzechowski, Chimera..., 258.

${ }^{30}$ Ibidem, 260.

${ }^{31}$ Cf. ibidem, 24-115.

${ }^{32}$ Cf. ibidem, 270-271.

33 „Jedenastozgłoskowce Wojciecha Wędrogowskiego”, in ibidem, 255. 
Utworowi temu odpowiadają słowa samego Orzechowskiego z pierwszej części rozprawy. Odnoszą się one do Franciszka Stankara, twórcy sekty tym bardziej niebezpiecznej, że o ile inne „toczą otwartą wojnę z Kościołem”, o tyle Włoch, „pozorując pokój, skwapliwie zbroi się przeciw Kościołowi” ${ }^{34}$, udaje lwa z pokolenia Judy, a w istocie jest ,podstępnym smokiem” ${ }^{35}$. Z tego powodu, precyzuje Orichovius, przypomina Chimere, „, co to z przodu jawi się lwem, z ogona wężem, w środku zaś kozą”, gdyż „ryczy niczym lew, rani niczym wąż, a cuchnie kozą" ${ }^{36}$. Ognistym i śmiercionośnym płomieniem, jaki zionął z paszczy monstrum, są tutaj poglądy Stankara tym bardziej niebezpieczne, że podkopują filary Rzeczypospolitej (tj. władzę duchowną i świecką współdziałające ze zobą) osadzone na fundamencie wiary w Boga w Trójcy jedynego oraz we współistotność Ojca i Syna ${ }^{37}$. Potwierdzeniem potworności Stankara był też fakt, że został on wygnany zarówno z ziemi rodzinnej, jak i z grona pobratymców w Pińczowie ${ }^{38}$.

Mityczną córkę Tyfona i Echidny, wychowaną przez władcę Licji, króla Amisodara, zgładził Bellerofont. Homer opisał go jako wojownika bez skazy,

${ }^{34}$ Stanisław Orzechowski, Chimera, 270.

${ }^{35}$ Ibidem.

${ }^{36}$ Ibidem. Orzechowski w Chimerze... jako źródło takiego wyobrażenia podaje na Iliadę Homera. Cf. ibidem, 343; Homer, Iliada, trans. Ignacy Wieniewski (Kraków: Wydawnictwo Literackie, 1984), 114, VI, w. 175-179 („Król rozkazał mu najpierw potworną zabić Chimerę. / Nie był to ziemski stwór, lecz bogi zesłały go ludziom: / Z przodu był lwem, a wężem był z tyłu, a kozą w pośrodku, / Z paszczy zaś zionął ognisty żar strasznego płomienia. / Lecz Bellerofont utrupił Chimerę przy bogów pomocy”). Vide również opisy Chimery: Hezjod, „Narodziny bogów (Theogonia)”, in idem, Narodziny bogów (Theogonia), Prace i dni, Tarcza, trans. et ed. Jerzy Łanowski (Warszawa: Prószyński i S-ka, 1999), 41, w. 319-325; Owidiusz, Przemiany, trans. Brunon Kiciński, ed. Jerzy Krókowski (Wrocław: Zakład Narodowy im. Ossolińskich, 1953), 185, IX, w. 650-653; Lukrecjusz, O naturze rzeczy, trans. Grzegorz Żurek (Warszawa: PIW, 1994), 201, V, w. 904-906.

${ }^{37}$ Cf. Stanisław Orzechowski, Chimera..., 276-339. Vide też wyjaśnienia zawarte na początku części drugiej: „Oto ryczy jak lew: «Boga nie godzi się prosić o wolność czynienia zła - czyż bowiem najwyższe dobro można prosić o cokolwiek innego poza dobrem?». Z tyłu, zza pleców, wypełza wąż i tę oto truciznę wyziewa w twoim królestwie: «Nie można prosić króla o wolność czynienia dobra. Nic nie może dziać się w państwie właściwie i wedle porządku, jeśli nie dzieje się za sprawą ojców». Pomiędzy lwem a wężem ukrywa się ta oto koza: «Poddani, na ile tylko mogą, winni reformować swoje kościoły nawet wbrew woli najwyższego urzędnika». Zdanie to cuchnie obrzydliwiej i ohydniej niż koza. Usuwa bowiem porządek społeczny i otwiera okno dla samowoli, przez którą to $\mathrm{z}$ wolności osuniemy się $\mathrm{w}$ niewole - $\mathrm{w}$ panowaniu niewola, a w niewoli panowanie trwać u nas będzie” (ibidem, 343). Poza tym vide „Jan Dymitr Solikowski na narodziny Chimery”, in ibidem, 265 („Do sypialni Lekceważenia wchodzi nieprzyjazna Kłótnia, / I bez zwłoki otwiera swe łono dla poczętego brzemienia. / Stamtąd, z ciemności Styksu, wychodzi sroga Chimera: / Z przodu lew, w środku koza, na końcu wąż. / Pożogą, przemocą, wojną, wszystkimi naraz siłami / Niszczy pożałowania godne sarmackie pola. / Niechaj Bóg wypędzi z naszych ziem tę zarazę, o to / Błagam i niechaj skryje ją na powrót w jeziorze Acherontu. / Lecz najpierw modlić się trzeba, by powstrzymać pyszną / Bestię sztukami chrześcijanskiego żołnierza”).

${ }^{38}$ Stankar opuścił Pińczów późną jesienią roku 1559. Cf. ibidem, 276, 291. 
któremu „nie poskąpiły [...] bogi urody i wdzięku męskiego” "39. Syn Glaukosa, dzięki pomocy Pegaza, zesłanego z niebios przez Atenę, wbił w gardło monstrum oszczep o ołowianym ostrzu, a ono stopiło się w ogniu buchającym z pyska i zalało wnętrzności Chimery. Do postaci pogromcy nawiązał Orzechowski na początku środkowej części rozprawy: nowym Bellerofontem miałby być on $\mathrm{sam}^{40}$, a za jego przykładem - Zygmunt II August pod warunkiem, iż nie powtórzy błędu Amisodara i nie pozwoli potworowi - Stankarowi i jego sekcie na zadomowienie się w państwie. Wszak, jak zauważa:

Przeciw tym zbrodniarzom i bezbożnikom, przeciw wrogom Boga i ludzi, wyznaczono z Bożego wyroku najświetniejszych wodzów - samych królów - aby w obronie Kościoła Chrystusa zażarcie walczyli przeciw wszelkim herezjom i by ze wszystkich swych sił bronili państwa Bożego przeciw państwu diabła ${ }^{41}$.

Zwycięstwo w potyczkach zapewnią - odpowiednio - albo racjonalne dowody wsparte umiejętnością wymowy, albo władza królewska i jej prerogatywy. Wątki te podejmują także autorzy wierszy dołączonych do wydań z 1562 i 1563 r.: Wojciech Wędrogowski, Melchior Pudłowski, Jakub Wujek. Pierwszy z nich wzywa do walki kapłanów, którym przykładem świeci Bellerofont - „nieustraszony żołnierz, wielce wymowny Sarmata" ${ }^{42}$. Drugi chwali cnoty i umiejętności wojownika - wybrańca bogów cieszącego się przychylnością samego Jowisza ${ }^{43}$, trzeci zaś kreśli wizerunek Bellerofonta-Orzechowskiego, który z pozłacanym toporem w dłoni dosiada Pegaza, biczem smaga Chimerę-Stankara i wieszczy jej koniec ${ }^{44}$.

Z tymi literackimi obrazami monstrum i jego zwycięzcy koresponduje rycina zdobiąca edycję Cholinusa (il.1) pt. Typus Christiani militis i przedstawiająca Bellerofonta - prawdziwego chrześcijańskiego rycerza.

${ }^{39}$ Homer, op. cit., 113, v. 153.

${ }^{40}$ Cf. „Ja jednak tę bladą, plującą ogniem Chimerę, zgładzę niczym drugi Bellerofont, ukazując prawdę niby mimochodem, a wymysły te poddam pod osąd rozumu" (Stanisław Orzechowski, Chimera..., 343).

${ }^{41}$ Ibidem, 344-345.

${ }^{42}$ Cf. „Jedenastozgłoskowce Wojciecha Wędrogowskiego”, 255.

${ }^{43}$ Cf. „Melchior Pudłowski Stanisławowi Orzechowskiemu”, in Stanisław Orzechowski, Chimera..., 264.

${ }^{44}$ Cf. „Stankar, gdy zrodził z potwornej masy Chimerę, / Wpierw przeraził się swojego płodu. / Mówi: «Już wkrótce, już niedługo spustoszymy sarmackie pola / Pod jej wodzą: któż bowiem takim siłom się przeciwstawi?» / Usłyszał to Orzechowski i, grożąc mu, topór / Pozłacany pochwycił w silną dłoń. / Już szuka konia (a z nieba zszedłszy Pegaz doń / Przybywa), dosiada go i biczem uderza. «Stankarze, gdzie teraz twoja odwaga? Gdzie siły ciała? / Będziesz zwyciężony, już wkrótce, będziesz zwyciężony»” (Jakub z Wągrowca, „Stankar, gdy zrodził z potwornej masy Chimerę...”, in ibidem, 266); „Czemuż, głupcze, się wściekasz? Sam Orzechowski Chimerę / Może zgładzić, jak to uczynił Bellerofont” (Jakub z Wągrowca, „Inne na Stankara”, in ibidem, 267). 


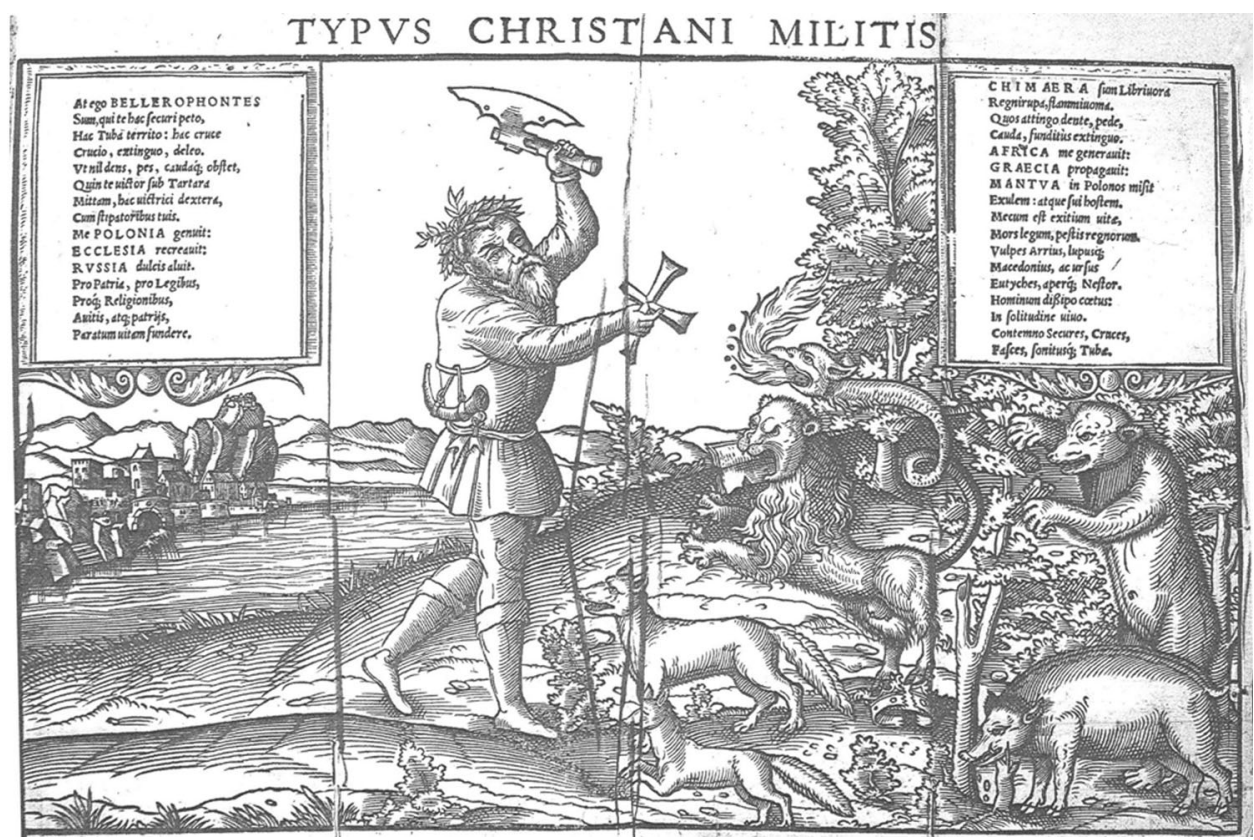

Il.1. Typus Christiani militis (rycina z: Stanislai Orichovii Roxolani Chimaera sive De Stancari funesta Regno Poloniae secta (Coloniae: apud Maternum Cholinum, 1563); egz. Biblioteki Narodowej w Warszawie (sygn. SD XVI.O.364 ad.)

Na jego oręż składają się: topór, krzyż i róg, a skronie zwieńczone są wieńcem laurowym. Wojownik przedstawia sie jako dziecko Polski, wykarmione przez Ruś i na nowo stworzone przez Kościół („Me Polonia genuit, / Ecclesia recreavit,/ Russia dulcis aluit”). Udaje się on na bój z Chimerą - potworem, który w lwim pysku trzyma podartą księgę i przednie łapy wyciąga w kierunku pogromcy, tylne depczą koronę, a z wężowego ogona wydostają się języki ognia. Jego opis pozwala utożsamić bestię ze Stankarem („Chimaera sum [...] / Africa me generauit, / Graecia propagauit, / Mantua in Polonia misit”), a towarzyszące jej dzikie zwierzęta z: Ariuszem (lis), Macedoniuszem (wilk), Eutychesem (niedźwiedź), Nestorem (dzik). Orzechowski na początku dzieła, zwracając się do Stankara, wyjaśnił: „z tych to zbrodniarzy, kłamców i oszustów zostałeś uformowany”, ,zwierz najszpetniejszy w swej brzydocie i ohydzie, którego boją się nawet sami heretycy" ${ }^{45}$.

Wspomnieć trzeba, że Jakub Górski (w liście do Przecławskiego) żołnierza chrześcijańskiego - Orzechowskiego utożsamiał z Herkulesem ${ }^{46}$, pogromcą siostry Chimery, czyli hydry lernejskiej, którą m.in. Izydor z Sewilli łączył z herezją ${ }^{47}$.

${ }^{45}$ Stanisław Orzechowski, Chimera..., 261.

${ }^{46}$ Jakub Górski..., 263.

${ }^{47}$ Cf. „Dicunt et Hydram serpentem, cum novem capitibus, quae Latine Excetra dicitur, quod uno caeso, tria capita excrescebant. Sed constat Hydram locum fuisse evomentem aquas, vastantem 
Wątek ten pojawił się także w wierszu Grzegorza Macera, przy czym tutaj miano herosa obdarzonego „herkulejską władzą niebios” nadano „nowemu wodzowi”, tj. papieżowi Piusowi IV. On to „uwalnia świętą religię od potworów, / Koi umysły niegdyś w srogie błędy / Uwikłane, wyściełając jasną drogę do gwiazd. / On bierze łupy i potrójną maczugę, / Dziką tę hydrę trzeba zabić ręką"48.

\section{Chimera i gerion Andrzeja Trzecieskiego}

Sylwa IV, napisana prawdopodobnie trzy lata po wydaniu Chimery..., została bezpośrednio wymierzona (tak jak sylwy III i X z Sylvarum libri II) przeciwko Piotrowi z Goniądza, którego Trzecieski słusznie uznał za polskiego Serveta $^{49}$. Sylwa III zawierała zwięzły wykład o naturze Chrystusa oparty na przekonaniu, że ,jest [On] Jehową, bóstwem zrodzonym z wiekuistego Ojca” („Et Christum Iehovam fatentur esse, / Aeterno genitum Parente Numen”) ${ }^{50}$, oraz o Duchu Świętym pochodzącym od Ojca i Syna. Utwór wieńczyła żarliwa prośba do Filipa Melanchtona (określanego jako „lux Teutoniae” - „chwała Teutonii" $)^{51}$ o przygotowanie lekarstwa na chorobę - herezję, dzięki jej zwolennikom bowiem szerzą się fałszywe sądy wywołujące niezgodę. Sylwę X rozpoczynało streszczenie poglądów głoszonych przez Ariusza, Macedończyka, Serveta i Gonezjusza, utrzymujących, jakoby Duch Święty był jedynie „darem Ojca” („donum Patris”), a Syn - „tworem Ojca” („Natus Patris factura”)" nym z Marii jako człowiek. „Ród wrogi Bogu” („gens inimica Deo”) ${ }^{53}$ zostanie jednak ukarany, a w kończącej wiersz modliwie poeta błagał Boga, aby jego przyjaciół - odszczepieńców, „zarażonych nieprawomyślnością antyariańską, nawrócił na prawdziwą wiarę " ${ }^{44}$ i ponownie przywiódł do „owczarni Chrystusa” („Vos reduces Christi grate amplectur ovile” $)^{55}$. Sylwa IV także podejmuje kwestię

vicinam civitatem, in quo uno clauso meatu, multi erumpebant. Quod Hercules videns, loca ipsa exussit, et sic aquae clausit meatus. Nam hydra ab aqua dicta est. Huius mentionem facit Ambrosius in similitudinem haeresium, dicens: Haeresis enim, velut quaedam hydra fabularum, vulneribus suis crevit; et dum saepe reciditur, pullulat, igni debita, incendioque peritura” (,Sancti Isidori Hispalensis Episcopi Etymologiarum libri XX", in Patrologia Latina, vol. 82, accurante Jean-Paul Migne (Brepols 1997), kol. 423, IX, 3, 34-35).

${ }^{48}$ Grzegorz Macer, „Na mnogie podzieloną części...”, in Stanisław Orzechowski, Chimera..., 266.

${ }^{49}$ Cf. „Kto jest zwolennikiem zarazy Gonezjuszowej, którą wydała na świat Serwetowa Chimera” („Pestem quisquis amat Gonezianam, / Quam Servetica protulit Chimaera”; Andrzej Trzecieski, op. cit., 246-247, v. 1-2); „Czy nie dość ci było odnowić szalone wymysły Serweta podobne do twoich, Gonezjuszu?” („Nec satis immanes fuerat renovasse furores / Serveti similes, Gonediane, tuis?”; ibidem, 274-275, v. 3-4).

${ }^{50}$ Ibidem, 246-247, v. 19-20.

${ }^{51}$ Ibidem, 250-251, v. 97.

${ }^{52}$ Ibidem, 274-275, v. 9, 11 .

${ }^{53}$ Ibidem, v. 6.

${ }^{54}$ Jerzy Krókowski, Komentarz historyczny, 608.

${ }^{55}$ Ibidem, 278-279, v. 63. 
Trójcy Świętej i to na tym temacie przede wszystkim koncentruje się uwaga autora, który nie grozi członkom sekt i ich przywódcom, nie upomina, nie zwraca się o pomoc do możnych tego świata, lecz wyraża smutek z powodu konieczności poruszenia tego zagadnienia oraz prosi Boga o wybaczenie ${ }^{56}$.

Na początku sylwy IV Trzecieski, aby wykazać, że arianie są pozbawionymi rozumu szaleńcami, przywołuje mitycznego Geriona, potwora o trzech głowach i trzech zrośniętych ze sobą tułowiach zrodzonego ze związku Chryzaora i Kalliore, a pokonanego przez Herkulesa ${ }^{57}$. Monstrum to pojawia się jednak nie w odniesieniu do poglądów heretyków, lecz - odwrotnie - członków prawdziwego Kościoła, których właśnie „Serwetowi sofiści” oskarżają o wiarę w tę wymyśloną bestię. Trzecieski zbija ich argumenty w zwięzły sposób wykładając naukę o Trójcy, przekazaną przez „czcigodną starożytność” (,alma vetustas”) ${ }^{58}$ :

Wierzy ona bowiem, że są trzy odrębne osoby, które mają jedną i tę samą boską naturę. Tak jeden jest Bóg, bo jakże można wierzyć, że jest trzech Bogów, wbrew zgodnemu świadectwu Pisma. Któż kiedy, jeśli tylko był przy zdrowych zmysłach, wierzył, że jest trzech Bogów albo trzy natury? Kto więc przeczy temu, że Ojciec, Syn i Duch pochodzący od ich obu jest jednym Bogiem, ten wierzy wbrew zgodnemu świadectwu Pisma, że jest trzech Bogów o różnej naturze ${ }^{59}$.

Wyjaśnienie Trzecieskiego odnoszące się do natury Boga w Trójcy jedynego skłania do wysnucia wniosku, że właśnie „nowi arianie”, a nie członkowie „owczarni Chrystusa”, uznają za prawdę podania o bajecznym potworze. W drugiej części sylwy autor odróżnia zwolenników „prawowitego Kościoła” („sincera Ecclesia”) ${ }^{60}$ od sekciarzy. Utrzymują oni, iż „tylko Ojciec jest największym Bogiem” („solus Pater est summus Deus”)", a Syna uznają za późniejszego i mniejszego od Ojca, a zatem nie za Boga ${ }^{62}$. W części trzeciej i ostatniej per analogiam z częścią pierwszą pojawia się znana nam już Chimera. Najsamprzód Trzecieski przywołuje ją (tak jak wcześniej Geriona), aby zacytować poglądy antytrynitarzy. Jednego Boga, „który jest Ojcem, Synem i Duchem Świętym” („Qui Pater est, Natus, Spiritus atque sacer”) ${ }^{63}$, nazywają oni „monstrum

${ }^{56}$ Cf. „Wybacz, Boże, że [...] tak zmuszony byłem mówić. Wielki bój wycisnął ze mnie te słowa, a co naprawdę jest w moim sercu, ty sam, boski Stwórco, dobrze widzisz” („Parce, Deus [...], / sic est lingua coacta loqui. / Ingenti nobis sunt haec expressa dolore, / Ut tu cor nostrum, conditor alme, vides"; ibidem, 257, v. 65-68).

${ }^{57}$ Vide opis Geriona: Hezjod, op. cit., 40, v. 287-294.

${ }^{58}$ Ibidem, 252-253, v. 3.

59 „Nam tres distinctas personas illa fatetur, / Naturam eiusdem quae Deitatis habent. / Sic Deus est unus, nam tres qui credere fas est / Contra scripturae consona verba Deos? / Quis tres esse Deos, vel tres quis credidit umquam / Naturas, sanae qui modo mentis erat? / Ergo qui Patrem Natumque et Flamen utroque / Procedens unum pernegat esse Deum, / Naturis tres distinctos hic esse fatetur, / Contra scripturae consona verba, Deos" (ibidem, 253-254, v. 5-14).

${ }^{60}$ Ibidem, v. 15.

${ }^{61}$ Ibidem, v. 17.

${ }^{62}$ Ibidem, 252-254, v. 18-28. 
trójkształtnym” („Hanc Triadem monstrum cur dicitis esse Chimaerae, / In Lycia monstrum quale triformis erat" $)^{64} \mathrm{z}$ Licji, choć trudno tu dostrzec podobieństwo do „potwornej Chimery” („,monstrosae [...] Chimaerae”) ${ }^{65}$ :

[...] przecież nie posiada [ona] w sobie nic ludzkiego, skoro wierzymy, że istnieją nie trzy, ale jedna natura, zarówno Ojca i Syna, jak i twoja Paraklecie. Jedna jest boskość w trzech osobach, jeden Bóg; tego uczy nas wyraźnymi słowy święta Biblia. Są więc według nas wieczni bez początku i bez końca, i równi sobie pod każdym względem, ale nie trzej Bogowie; jeden bowiem jest Bóg i to jest właśnie owa wielka tajemnica, w jaki sposób trzej są jednym Bogiem ${ }^{66}$.

Następnie Trzecieski, podobnie jak w przypadku Geriona, wykorzystuje Chimerę, aby pokazać podstawowe założenia pozbawionej sensu doktryny „Serwetowych sofistów i zgrai nowych arian”. Wymyślili oni trzy natury: Ojca obdarzonego cechami lwa - króla, głowy i pierwszej cześci ciała potwora, Syna - niższego Boga, o sile mniejszej niż moc króla i zdolnego jedynie do tego, by, jak koza, niewolniczo wypełniać cudze rozkazy, Ducha skojarzonego ze smokiem znajdującym się na końcu monstrum, któremu nie należy się żadna cześć (z powodu jego najmniejszego znaczenia) ${ }^{67}$. „W ten sposób - dowodził autor Sylvarum libri - każdy widzi, że wasza Chimera składa się z trzech części, nierównych sobie swą naturą” („Sic tribus ex istis vestram constare Chimaeram/ Natura imparibus cernere quisque potest") ${ }^{68}$.

Nawiązanie do mitologicznego stworzenia pozwoliło także na zwięzłe streszczenie podstawowych założeń nauki Serveta. W przywoływanym już dziele $D e$ Trinitate erroribus... podważył on dogmat o Trójcy. Podstawą sprzeciwu Hiszpana było przekonanie, że w Piśmie Świętym nie pojawiają się upowszechnione przez scholastyczna teologię terminy, takie jak m.in.: essentia, persona, relatio, communicatio, idiomatum. Zostały one wymyślone przez bezbożników, dążących do „ufilozoficznienia” jasnych i prostych treści Słowa Bożego, a przez to - do zafałszowania tego, co stanowi o wyższości religii chrześcijańskiej, czyli postaci Chrystusa, nie „metafizycznego Syna”, lecz historycznego człowieka. Jak przekonuje Lech Szczucki, Servet osoby Boskie zastąpił „dyspozycjami” („dyspensacjami”), tj. stanami, przejawami, manifestacjami wszechmocnego i przedwiecznego Boga Ojca, który przy ich pomocy udziela się ludziom. Z tego powodu autor De Trinitate erroribus... wyróżnił trzy fazy rozwojowe „Trójcy dyspozycji”. Pierwszą był Chrystus

${ }^{63}$ Ibidem, 254-255, v. 30.

${ }^{64}$ Ibidem, v. 34.

${ }^{65}$ Ibidem, v. 35.

${ }^{66}$, ,[... Humanae siquidem nil rationis habet, / Cum non tres, sed naturam nos credimus unam,/ Ut Patris et Nati, sic Paracletae tuam. / Una tribus Deitas, Deus attamen Unus, id ipsum / Perspicuis verbis Biblia sacra docent. / Aeternos sine principio, sine fine, paresque / Quolibet, at non tres novimus inde Deos, / Unus enim Deus est, grande est mysterion illud, / Tres unus quanam sint ratione Deus" (ibidem, v. 36-44).

${ }^{67}$ Ibidem, 256-257, v. 53-62.

${ }^{68}$ Ibidem, v. 63-64. 
istniejący jako Słowo Boga - jedna z form, przejawów boskości. Przez Wcielenie (druga faza) Słowo stało się konkretną substancją, Synem, ale ten, w przeciwieństwie do Słowa, nie został uznany za współwiecznego z Ojcem. Duch Swięty mógł działać w sercu człowieka jako moc, Boża energia tylko do rozpoczęcia fazy ostatniej - wiecznego królestwa Chrystusa, które Syn miał przekazać Bogu Ojcu. Wówczas to, kiedy nastanie panowanie jedynego Boga, nie będzie potrzeby istnienia rzecznika czy pojednawcy, ale również ustanie „dyspensacja Trójcy”"69. Poglądy Serveta stanowiły inspirację dla Piotra z Goniądza. W traktacie O Trzech, to jest o Bogu, o Synu jego i o Duchu Ś. Przeciwko Trójcy sabelijańskiej tak streszcza on ortodoksyjną naukę o Trójcy Świętej zawartą w Credo:

Gdy mówią: „Bóg jeden jest bytnością, a trojaki w personach”, nic się inego nie daje znać, jedno gdyby wyraźnie tak mówili: „Bóg jest jeden Duch, a w tym jednym trzej są, z których jeden jest Ojcem, drugi Synem, a trzeci Duchem S.”. A tak musiałoby być coś takiego jednego, co by nie było ani Ojcem, ani Synem, ani Duchem Ś., ale i Ojca, i Syna, i Ducha Ś. jakąś rzeczą społeczną, którą oni istnością zowią. A zaś w tej to rzeczy społecznej byliby trzej i nie mogliby być co inego, jedno trzej Duchowie, jeśliby wszyscy trzej niecielesnej substancyjej byli. Co jeśliby nie pozwalali, aby ci trzej byli Duchowie, iż też i tego nie pozwalają, aby byli trzy substancje cielesne, tedyćby to musiało być, żeby byli trzej, a nic by nie byli, ponieważby ani trzej Duchowie byli, ani trzy substancyje cielesne. A za tym by szło, żeby bałwana mózgu swego chwalili, iż nie tylko Ojca, ale też i Syna z nim chwalą, i Ducha Ś. wespół z obiema. Abowiem Boga jednego nie może żaden wespół z drugim chwalić, bo jest jeden. A kto kogo z kim drugim wespołek chwali, ten nie jednego chwali, ale tyle ich, ile ich jest wespołek. A przeto - jakom już osądził - gdyby Ojciec i Syn, i Duch Ś. nie byli trzej, ale trzy tylko imiona jednego, tedyby trzech wespół chwalac, byliby bałwochwalce, boby to chwalili, co by nic nie było. A iżby wespół z Ojcem i Synem Ducha Świętego chwalili, świadczy ich kredo, które zawsze na mszach śpiewają ${ }^{70}$.

Gonezjusz, wzywając w zakończeniu do odrzucenia trynitaryzmu, jego zwolenników nazywał heretykami i następcami Sabeliusza ${ }^{71}$ wierzącymi w wielu (bo w trzech) bogów, a nie w Boga jedynego. Podobne stanowisko zajął Grzegorz Paweł z Brzezin w wydanym w 1564 r. utworze pt. O rożnicach teraźniejszych to jest co o jednym Bogu Ojcu i Synu Jego jednorodzonym i o Duchu Świętym prawdziwie rozumieć mamy. Druk ten zawiera rozdział o prawdziwym i fałszywym, antykrystowym kościele. Zwolenników tego ostatniego wyróżnia wiara nie w ,jednego Boga prawdziwego”, lecz w „trzech Bogów” lub „Boga trojakiego”, co „się czasem kurczy, aby jednym był, a czasem się rozszerza, aby był trojakiem”72.

${ }^{69}$ Poglądy Serweta referuję w oparciu o uwagi Lecha Szczuckiego, Michat Serwet..., 15-17.

${ }^{70}$ Piotr z Goniądza, op. cit., 44.

${ }^{71}$ Jednego z pierwszych teologów (III w. n.e., Libia) negujących odrębność osób Trójcy Świętej. O wczesnochrześcijańskich poglądach na Trójcę Świętą vide Krzysztof Sordyl, Wczesnochrześcijańskie pojęcie Boga. Polemiczne aspekty teologii Nowacjana w „De Trinitate” (Kraków: Wydawnictwo WAM, 2007).

${ }^{72}$ Grzegorz Paweł z Brzezin, O rożnicach teraźniejszych to jest co o jednym Bogu Ojcu i Synu Jego jednorodzonym i o Duchu Świętym prawdziwie rozumieć mamy, ed. Konrad Górski et Władysław Kuraszkiewicz (Wrocław: Zakład Narodowy im. Ossolińskich, 1954), 65. 


\section{Zakończenie}

Andrzej Trzecieski młodszy w In sophistas Serveticos..., podobnie jak Stanisław Orzechowski w znanej twórcy sylw Chimerze..., przywołał mityczną Chimerę i Geriona. Nawiązania do tych monstrów służyły jednak nie tyle wyrazistemu określeniu charakteru przywódców ruchu antytrynitarskiego czy sposobu ich działania, ile raczej określeniu istoty i natury ich twierdzeń: „potwornych”, bo niebezpiecznych i trudnych do odparcia. W rozprawie Orzechowskiego pojawił się także Bellerofont utożsamiony $\mathrm{z}$ autorem, papieżem Piusem IV, królem Zygmuntem Augustem... Ci żołnierze chrześcijańscy mieli zjednoczyć się w walce $\mathrm{z}$ bestią, która wymagała użycia różnych środków: od logicznych argumentów ubranych w słowa po możliwości, jakie stwarzało zgodne działanie aparatu władzy zarówno duchownej, jak i świeckiej. Trzecieski w sylwie IV nie wyposażył „swojego” Bellerofonta w żadną broń poza „prostą wiarą”: ona miała „starczyć za rozum”, a rozum - uznać niższość wobec słowa ${ }^{73}$. Tylko taka postawa warunkowała przyjęcie tajemnicy o Bogu w trzech Osobach, a miejscem właściwym do jej rozważania było serce, w które w pełni wejrzeć potrafi jedynie Boski Stwórca, jak czytamy w Psalmie 37 parafrazowanym przez Trzecieskiego w zakończeniu sylwy IV ${ }^{74}$. Jahwe wynagrodzi także wiernych, aczkolwiek, o czym przypominał Mikołaj Rej w wierszu Bóstwo jedyne (dołączonym do drugiego wydania Zwierzyńca z 1574 r.), trofeum zostanie wręczone wybranym dopiero wtedy, kiedy dopełnią się losy świata:

Bóstwo, iż tylko jedno nigdy nie rozdzielne,

O tym, że tak jest świadectw wszytki pisma pełne;

A iż je w Krystu Panie zupełnie być znamy,

Przetoż Bogiem i panem swym go wyznawamy.

Jakoż i sprzeciwnicy jawnie to uznają,

Acz dziwne błędy swoje o nim rozsiewają.

Kiedy świat przyjdzie sądzić w boskim majestacie,

Że jest Bogiem prawdziwym, tam jawnie poznacie ${ }^{75}$.

${ }^{73} \mathrm{Cf}$. „Tutaj nasz rozum musi się poddać, prosta wiara starczy za rozum [...]” („Hic nostrae mentis ratio succumbat oportet, / Sufficit hic simplex pro ratione fides"; Andrzej Trzecieski, op. cit., 254-255, v. 45-46).

${ }^{74}$ Ibidem, 256-257, v. 66-68. Vide fragment tego psalmu za Biblia brzeska: „Panie, wszytka moja chuć jest przed Tobą, a wzdychanie moje nie jest tajemne tobie”. Biblia brzeska 1563, ed. Peter Królikowski (Clifton - Kraków: Kalwin Publishing - Collegium Columbinum, 2003), 531.

${ }^{75}$ Mikołaj Rej, Zwierzyniec 1562, ed. Wilhelm Bruchnalski (Kraków: Akademia Umiejętności, 1895), 292. 


\section{CHIMERA IN DISPUTES OVER THE HOLY TRINITY \\ IN THE SIXTIES OF THE $16^{\mathrm{TH}}$ CENTURY \\ (EXEMPLIFIED BY SILVA RERUM IV BY ANDRZEJ TRZECIESKI)}

\section{Sum mary}

The article discusses the way in which the symbolism of chimera, a mythic monster from Lycia (with lion's mouth, goat's torso and serpent's tail) slayed by Bellerophon, was used in Silva Rerum IV (In sophistats Serveticos et novorum arianorum faecem censurae catholicae, around 1565) by Andrzej Trzecieski junior. This work is also a testimony to the stormy disputes with Arianism followers which engaged Stanisław Orzechowski through, inter alia, a treatise known to Trzecieski, namely Chimaera sive de Stancari Fvnesta Regno Poloniae Secta (1562). The author of Sylvarum libri II undoubtedly based his work on Orzechowski's piece, but referred to chimera in a different way. Chimera in Trzecieski's view was used not as a direct attack against particular persons, to defend the papacy, the ecclesiastical power and king's majesty, but above all to exemplify the heretics' beliefs upon the Holy Trinity or the everlasting divinity of Christ, and to show the reasons for the heretics' mistakes. 